\title{
Reticular Growth Pattern
}

National Cancer Institute

\section{Source}

National Cancer Institute. Reticular Growth Pattern. NCI Thesaurus. Code C157705.

A morphologic finding where the cells proliferate and give a net-like appearance to the lesion showing multiple spaces of varying sizes in between the cells. 